\title{
A FILOSOFIA DO DIREITO E O PENSAMENTO DE KARL MARX: A RELAÇÃO ENTRE OS DIREITOS HUMANOS E O MARXISMO
}

Márcio Bonini Notari ${ }^{1}$

RESUMO: O presente artigo busca analisar o direito enquanto fenômeno jurídico no mundo contemporâneo, a partir dos pressupostos teóricos de Karl Marx e Frederich Engels, estabelecendo o nexo de causalidade entre os direitos humanos e o pensamento marxista. Essa perspectiva tem como pressuposto o direito, não apenas como um conjunto de regras e normas jurídicas que regulam a paz social, mas sim enquanto componente da história e das relações econômicas materiais, dentro da lógica operacional do sistema capitalista e do mercado e das relações produtivas, estabelecendo determinadas instâncias que possibilitem a própria reprodução do sistema. Conforme as demandas capitalistas se impunham, os instrumentais jurídicos eram criados, sem atender ao bem comum, mas a práxis, a história social e produtiva do homem. O problema que envolve a temática dos direitos humanos, conforme será abordado, diz respeito à liberdade e a igualdade real, como forma de concretização a partir da práxis e, numa perspectiva relacional, histórica e dialética.

Palavras chaves: Direitos humanos, marxismo, relações produtivas e capitalismo.

\section{THE PHILOSOPHY OF LAW AND THE THOUGHT OF KARL MARX: THE RELATIONSHIP BETWEEN HUMAN RIGHTS AND MARXISM}

\begin{abstract}
This article seeks to analyze law as a legal phenomenon in the contemporary world, based on the theoretical assumptions of Karl Marx and Frederich Engels, establishing the causal link between human rights and Marxist thought. This perspective presupposes law, not only as a set of rules and legal norms that regulate social peace, but as a component of historical and material economic relations, within the operational logic of the capitalist system and the market and productive relations, establishing certain instances that allow the reproduction of the system itself. As capitalist demands were imposed, legal instruments were created, without regard to the common good, but praxis, the social and productive history of man. The problem that involves the subject of human rights, as it will be approached, concerns freedom and real equality, as a form of concretization from praxis and, from a relational, historical and dialectical perspective.
\end{abstract}

Key words: Human rights, Marxism, productive relations and capitalism.

\section{INTRODUÇÃO}

\footnotetext{
${ }^{1}$ Graduado em Direito pela Universidade Católica de Pelotas/RS - UCPEL. Especialista em Direito e Processo do Trabalho pela Faculdade Atlântico Sul, Pelotas/RS. Especialização em Filosofia pela Universidade Federal de Pelotas/RS. Mestre em Direitos Sociais e Políticas Públicas pela Universidade de Santa Cruz do Sul UNISC/RS. Professor do Colegiado de Direito da Universidade da Região da Campanha, Campus Santana do Livramento/RS. Contato: marciobnotari@gmail.com
} 
Se o assunto a pesquisar for o positivismo, um dos clássicos a ser recomendado será o pensador Augusto Comte; em se tratando de Contratualismo, será leitura obrigatória as obras de John Locke, Hobbes e Rousseau; sendo o assunto Jus positivismo, os nomes clássicos são dos pensadores Hans Kelsen e Norberto Bobbio; ao tratar de livre mercado economia, a remissão se faz a Adam Smith; se a abordagem tratar do tema do sistema prisional, imediatamente se faz menção as obras de Michael Foucault; em relação a economia e direito se faz remissão ao pensamento de Karl Marx.

A globalização do capital, a sociedade de consumo, as desigualdades econômicas e sociais, as crises na economia de superprodução, a propriedade privada dos meios de produção (transporte, telefonia, telecomunicações, bancos, educação), a redução dos direitos sociais e trabalhistas, às crises econômicas, fome, miséria, desequilíbrio ambiental, as guerras armamentistas, os fundamentalismos violadores dos direitos humanos, levadas ao extremo, acarretam em crise do modelo preconizado pela sociedade burguesa; ainda, o espectro do comunismo subsistirá rondando a história, sendo importante remontar ao espólio marxista, quanto à compreensão da sociedade; sendo assim, apresenta-se o seguinte problema: é possível estabelecer uma teoria geral do Direito marxista e fazer uma conexão com os direitos humanos?

Sendo assim, propõe-se no presente estudo a relação entre Direitos humanos e o Estado em Marx, em sua teoria epistemológica, apresentando uma proposta de superação da dogmática normativista, da lógica formal, da mera declaração e proclamação de direitos e de todo um universo rígido de normas. O objetivo do presente trabalho será analisar o direito, enquanto fenômeno jurídico e social moderno e contemporâneo a partir do marxismo como vertente teórica sobre as relações jurídicas e sociais, tendo como pressuposto as relações econômicas e materiais da vida.

Considerando que nosso trabalho é de natureza bibliográfica, o método de abordagem a se adotado no seu desenvolvimento será o dedutivo, tendo pressuposto argumentos gerais, para argumentos particulares; quanto ao procedimento será analítico e o histórico crítico, procurando dar tratamento localizado á matéria objeto de estudo.

\section{MARX: HISTÓRIA E REVOLUÇÃO}


Karl Heinrich Marx (1818-1883) ${ }^{2}$ não pode, de forma alguma, ser negligenciado na análise jurídico-social de construção do Direito moderno e contemporâneo. Pelo contrário, é este filósofo alemão, proveniente da Renânia, que, inclusive, habitou em suas peregrinações a França e a Inglaterra, como jornalista e escritor, o causador de inúmeras transformações efetivas nas estruturas do pensamento e da legislação dos séculos XIX e XX, tamanha a repercussão de suas lições, reivindicações e propostas, abordando da legislação do século XIX e XX, no período pós-revoluções liberais (Francesa e Americana), pós-revoluções liberais, pós-codificação do direito, tendo suas lições, tecendo críticas a idéia bem comum e a vontade geral do Estado, ao paradigma dos Direitos Humanos e individuais.

Marx, porém, não surgiu sozinho, em seu momento histórico, e também não lecionou aquilo que não era uma solicitação necessária em sua época, especialmente, no período pósRevolução Industrial, pós-Revolução Francesa, pós-Codificação do Direito. Ademais, os prenúncios dos movimentos sociais e das reivindicações teóricas a serviço dos explorados vinham ecoando desde o século XVIII, com destaque para inúmeros escritores. O marxismo encontra terreno para sua sedimentação como alicerce do edifício jus filosófico do direito.

Assim é que, em aliança com a figura de Friedrich Engels (1820-1895), aparece Karl Marx como o expoente mais destacado do socialismo científico, desenvolvendo com autenticidade a idéia de um materialismo histórico. O homem destaca- se de sua análise como o principal elemento de reflexão, mas não o homem universal ou espiritual, ou ainda, o homem racional, mas o individuo enquanto força produtiva, na esfera da economia, num processo sequencial de causa e efeito, determinado pelas transformações e contradições sociais entre o capital e o trabalho. ${ }^{3} \mathrm{Na}$ ida para a Inglaterra, tendo passado pela cidade de Colônia e, ao visitar a sede do jornal Gazeta Renana, conheceu Karl Marx, chefe da redação. A partir de então, estabeleceram uma relação de amizade que perduraria por longos anos e

\footnotetext{
${ }^{2}$ Filho de um advogado e conselheiro de justiça e descendente de judeus, Karl Heinrich Marx (1818-1883) nasceu em Treves, capital da província alemã da Renânia. Após os estudos preliminares em sua terra natal, matriculou-se na Universidade de Bonn, onde iniciou o curso de Direito, logo interrompido, pois seu interesse maior concentrava-se nos estudos de História e Filosofia. Ingressou posteriormente na Universidade de Berlim, onde se influenciou pelo pensamento ateu e liberal-democrático da esquerda hegeliana, tendo inclusive realizado sua tese de doutoramento em filosofia (NADER, 2012, p. 257).

${ }^{3}$ É por afirmar que a sociedade se constitui a partir de condições materiais de produção e da divisão social do trabalho, que as mudanças históricas são determinadas pelas modificações naquelas condições materiais e naquela divisão do trabalho, e que a consciência humana é determinada a pensar as idéias que pensa por causa das condições materiais instituídas pela sociedade, que o pensamento de Marx e Engels é chamado de materialismo histórico. Materialismo porque somos o que as condições materiais (as relações sociais de produção) nos determinam a ser e a pensar. Histórico porque a sociedade e a política não surgem de decretos divinos nem nascem da ordem natural, mas dependem da ação concreta dos seres humanos no tempo (CHAUÍ, 2002, p. 537).
} 
escrevendo uma vasta produção literária sobre a política, religião, econômica, direito, sociologia, família, propriedade privada, Estado (NADER, 2012, p. 258).

O percurso intelectual marxista retrata certa preocupação com uma ampla variedade de temas ligados a filosofia, a economia, ao direito, a história, colocando sua obra a serviço da classe proletária. Dentre as principais obras escritas por Marx, está os Manuscritos Econômicos - Filosóficos (1844), A Sagrada Família (1844), Teses sobre Feurbach (1845) a Ideologia Alemã (1846), a Miséria da Filosofia (1847), o Manifesto Comunista (1848), O 18 Brumário de Luís Bonaparte (1851) e, por fim, O Capital (1867), todas em conjunto Friedrich Engels. Conforme as lições de Mascaro (2002, p. 92), “o Marx filósofo, cuja repercussão para a filosofia do direito é das maiores de toda a história, começa não pelos variados marxismos, mas por meio de seus textos e de suas ideias". Conceituando, ensina Norberto Bobbio:

\begin{abstract}
Entende-se por Marxismo o conjunto das idéias, dos conceitos, das teses, das teorias, das propostas de metodologia científica e de estratégia política e, em geral, a concepção do mundo, da vida social e política, consideradas como um corpo homogêneo de proposições até constituir uma verdadeira e autêntica "doutrina", que se podem deduzir das obras de Karl Marx e de Friedrich Engels. A tendência, muitas vezes manifestada, de distinguir o pensamento de Marx do de Engels surge dentro do próprio Marxismo, ou seja, ela própria se constitui numa forma de Marxismo. Identificam-se diversas formas de Marxismo, quer com base nas diferentes interpretações do pensamento dos dois fundadores quer com base nos juízos de valor com que se pretende distinguir o Marxismo que se aceita do Marxismo que se rejeita: por exemplo, o Marxismo da Segunda e da Terceira Internacional, o Marxismo revisionista e ortodoxo, vulgar, duro, dogmático, etc. (BOBBIO, 1999, p. 738)
\end{abstract}

Para reconstrução do pensamento marxista sobre o poder do Estado é necessário, desse modo, em muitos momentos, socorrer-se a suas ideias dispersas e, portanto, fragmentadas as quais serão encontradas em diversos manuscritos econômicos, políticos e históricos; assim, como membro da chamada juventude hegeliana de esquerda, contrária à filosofia do direito de Hegel, não há uma literatura especifica da obra de Marx, que delimita seu objeto acerca do problema do Estado, assim como, de igual modo, inexiste, em sua obra a possibilidade de retirar deste problema, tendo em vista fragmentos importantes e ilustrativos.

É importante ressaltar que o momento histórico da teoria marxista foi marcado pela sucessão da indústria e o surgimento da classe proletária e obreira, em especial, a Revolução Industrial (Inglaterra, segunda metade do século XVIII), estendida a todos os países civilizados do mundo, com o surgimento de duas classes: a classe dos grandes capitalistas, denominado burguesia, que, em todos os países civilizados, já estão de posse exclusiva de 
todos os meios de subsistência, das matérias primas e dos instrumentos (máquinas, fábricas), necessários à produção dos meios de existência. A classe dos despossuídos, dos que, em virtude do desapossamento, são obrigados a vender seu trabalho aos burgueses para receber, em troca, os meios necessários á sua subsistência, ou seja, proletários, isto é, o proletariado.

Em todas as sociedades que existiram até nossos dias tem sido uma história da luta de classes. Homem livre e escravo, patrício e plebeu, senhor e servo, mestre de corporação e oficial, numa palavra, opressores e oprimidos, em constante oposição, têm vivido numa guerra ininterrupta, uma guerra que termino sempre, ou por uma transformação evolucionária da sociedade inteira, ou pela destruição das classes em luta. A sociedade burguesa moderna, na visão marxista, nasceu das ruínas da sociedade feudal, não abolindo os antagonismos de classes, não fez senão substituir velhas classes, velhas condições de opressão, velhas formas de luta por outras novas, simplificando os antagonismos de classes. A sociedade divide-se cada vez mais em dois vastos campos opostos, em duas grandes classes diametralmente opostas: a burguesia e o proletariado (MARX, Et al, 2005, p. 84).

Engels coloca o seguinte questionamento: Como surgiu o proletariado? Como resposta o proletariado nasceu com a Revolução Industrial, produzida na Inglaterra, na segunda metade do século 18, que logo se estendeu a todos os países civilizados do mundo. E encerra a resposta ao questionamento com a seguinte conclusão: a) a classe dos grandes capitalistas, que, em todos os países civilizados, já estão de posse exclusiva de todos os meios de subsistência, das matérias primas e dos instrumentos (máquinas, fábricas etc), necessários à produção dos meios de existência. (ENGELS, Et al, 2005, p. 41).

Cada etapa da evolução percorrida pela burguesia era acompanhada de um progresso político correspondente. Classe oprimida pelo despotismo feudal, associação armada administrando-se a si própria na comuna, República urbana independente, terceiro estado, tributário da monarquia, depois, durante o período manufatureiro, contrapeso da nobreza na monarquia feudal, pedra angular das grandes monarquias, a burguesia, desde o estabelecimento da grande indústria e do mercado mundial, conquistou, finalmente, a soberania política exclusiva no Estado representativo moderno. O governo do estado moderno não é se não um comitê para gerir os negócios comuns de toda a classe burguesa (MARX, Et al, p. 85). De tal modo que, ensina Bobbio,

El trastocamiento de la relación entre sociedad civil y Estada operado por Marx respecto a la filosofía política de Hegel marca una verdadera ruptura con toda la tradición de la filosofía política moderna. Mientras ésta tiende a ver en la sociedad 
anterior al Estado (ya sea el estado de naturaleza de Hobbes, o la sociedad natural de Locke, o el estado de naturaleza o primitivo de Rousseau del Contrato social, o el Estado de relacicnes de derecho privado-natural de Kant, o precisamente la familia y la sociedad civil de Hegel) una subestructura, realidad, sí, pero efímera, destinada a ser resuelta en la estructura del Estado en que sólo el hombre puede conducir una vida racional, y por consiguiente a desaparecer en todo o en parte, una vez constituído el Estado, Marx considera al Estado, entendido como el conjunto de las instituciones políticas, en que se concentra la máxima fuerza imponible y disponible en una determinada sociedad, pura y simplemente como una superestructura respecto a la sociedad prestatal, que es el lugar donde se forman y se desarrollan las relaciones materiales de existencia y, en cuanto superestructura, destinado a desaparecer a su vez en la futura sociedad sin clases. (BOBBIO, 1999, p. 135).

Nesse ponto, ao contrário de Hegel, para quem o Estado seria a instância de racionalidade do homem e da história, para o marxismo o Estado nasceria das contradições e da "dialética" do tecido social, em função das relações de produtivas e materiais de existência que tomam determinado grau de desenvolvimento, não sendo o poder estatal a instancia pacificadora dessa sociedade, assim como, de suas relações de produção sendo envolvido numa superestrutura que se coloca como força executório-interventiva a serviço da classe capitalista, tendo como foco a manutenção da exploração e do conflito produtivo existente.

Conforme preceitua Frederich Engels, o Estado não constituiria uma realidade da idéia moral, a imagem e concretude da razão, como pretendia Hegel, mas seria um produto da sociedade numa certa fase do seu desenvolvimento, embaraçado numa insolúvel contradição interna, dividido em antagonismos inconciliáveis, notadamente de classes antagônicas entre si, com interesses econômicos conflitantes. Em razão disso, para que não haja uma luta estéril, o Estado exsurge com uma necessidade de força acima da sociedade, como pacificador do conflito e da ordem, estado acima da sociedade. (ENGELS, 1984, p. 181).

Marx haveria de agregar às ideias hegelianas as idéias de Feuerbach, no sentido da ação, a real operação, a realidade das coisas superando em importância o momento das ideias abstratas. Feuerbach, e seu naturalismo, contribuíram para a formação de um Marx concreto. Todavia, não se torna possível desconsiderar a dialética hegeliana e a ideia do poder do homem sobre a natureza e a sua respectiva separação no contexto do pensamento marxiano. (BITTAR, ALMEIDA, 2015, p. 402). Assim, o pensamento marxista tem como alicerce o compromisso com o social, com a práxis, com a ação política, afastando-se do idealismo hegeliano, ou mesmo das perspectivas contemplativas anteriormente existentes. De modo que,

A consubstanciação do justo e do racional no Estado, e não no indivíduo nem na sociedade civil, faz com que Hegel rompa com toda a tradição estabelecida na modernidade sobre a filosofia política e jurídica. $\mathrm{O}$ denominador comum de todo o 
pensamento jusfilosófico moderno foi o individualismo e, em consequência, a teoria do contrato social. O individualismo, fazendo do sujeito sede da racionalidade e cerne dos direitos. O contratualismo, como manifestação da racionalidade e da vontade individual, portanto momento superior que dava razão de ser ao próprio Estado. Hegel romperá com essa ordem de explicações. O Estado não terá fundamento nem no indivíduo nem na sociedade civil, que lhe são momentos inferiores. A concretização do direito no Estado faz com que não se indague a respeito da moralidade individual. Se Kant praticamente equivalia a moralidade com o justo jurídico, porque os dois saem do mesmo imperativo categórico, de uma razão individual, Hegel rompeu essa equivalência. Individualidade e moralidade são reinos que devem ser subordinados a um momento superior, que é o da eticidade consubstanciada no Estado (MASCARO, 2016, p. 226).

Da concepção de Marx e Engels, pode se extrair uma tríplice antítese do Estado; a primeira, como sendo o aparelho coercitivo que detém a violência concentrada e organizada da sociedade; em segundo, o estado como um instrumento, o comitê da classe dominante, numa concepção particularista, em contraposição a concepção universalista de Hegel; em terceiro, o Estado como movimento subordinado à sociedade civil, sendo esta a condicionante e reguladora do Estado, num sentido negativista, contrário à concepção positiva, condição essencial da racionalidade do pensamento hegeliano. O Estado é uma possui caráter transitório, a qual deve ser suprimida (BOBBIO, 1982, pp. 22 - 23)

Nas Teses ${ }^{4}$ sobre Fuerbach, o pensamento marxista se desloca totalmente da tradição filosófica até então estabelecida. Não mais um conhecimento especulativo, meramente contemplativo. Trata-se, pois, de um pensamento da práxis revolucionária, objetivando a transformação. É assim que Marx fundará sua filosofia sobre uma práxis. Na Tese III, esse exponencial ficara claro ao elencar: "A coincidência da modificação das circunstâncias com a atividade humana ou alteração de si próprio só pode ser apreendida e compreendida racionalmente como práxis revolucionária”.

A compreensão do homem por meio relacional, processual, histórico estava também de certa forma na sustentação metodológica de todo o edifício da filosofia hegeliana. No entanto, enquanto Hegel propugnava o Estado como momento superior da história, Marx ligou-se ao hegelianismo muito mais por meio de seu método, sua lógica, que propriamente por suas conclusões. Essa processualidade importava muito mais a Marx do que o idealismo hegeliano que chegava a idéia de "razão no Estado". E, como insistira na crítica a Feuerbach, a processualidade humana é relacional, com base na atividade humana.

\footnotetext{
${ }^{4}$ Escrito por Marx durante a primavera de 1845. Redigido e publicado pela primeira vez em 1888, por Engels como apêndice da edição em folheto à parte de seu Ludwig Feuerbach. Publica-se de acordo com o texto da edição em folheto à parte, de 1888, após confronto com o manuscrito de Marx. Traduzido do espanhol.
} 


\title{
CAPITALISMO E DESIGUALDADES
}

O movimento de passagem da filosofia moderna para a contemporânea de uma filosofia da consciência em Kant para uma filosofia da práxis em Marx, representa não só uma tomada de posição distinta em relação a certos problemas teóricos e formais, mas, muito mais que isso, uma radical transformação em relação à compreensão da filosofia do direito e da própria vida do jurista. A tradição filosófica moderna lastreada nos problemas do conhecimento, do indivíduo como base de afirmação racional do mundo, gerou para o direito uma série de derivações também individualistas e racionalistas (MASCARO, 2002, p. 09).

O pensamento marxista, é de se dizer, ainda está por ser desbravado pela filosofia do direito, a qual está baseada no seio da ordem e da justificativa do poder legal. Por outro lado, quando realiza a crítica, o faz dentro de seus limites individualistas e racionalistas. Escapar deles é deveras fundamental na atual encruzilhada das estruturas sociais contemporâneas, baseada na práxis, e não no idealismo alemão hegeliano, fonte de iluminação dos problemas sociais e filosóficos de nosso mundo contemporâneo; assim, as raízes históricas do pensamento jurídico, negações e debates da jusfilosofia têm nessa passagem do pensamento moderno para o contemporâneo, razões para elucidar a importância do sistema de relações sociais e econômico-produtivas (capitalismo), inaugurada na Idade Moderna, estendendo-se até os dias atuais. De tal modo que,

\begin{abstract}
A abstração do Estado como tal pertence somente aos tempos modernos porque a abstração da vida privada pertence somente aos tempos modernos. Na abstração do Estado político é um produto moderno. Na Idade Média havia servos, propriedade feudal, corporações de ofício, corporações de sábios etc.; ou seja, na Idade Média a propriedade, o comércio, a sociedade, o homem são políticos; o conteúdo material do Estado é colocado por intermédio de sua forma; cada esfera privada tem um caráter político ou é uma esfera política; ou a política é, também, o caráter das esferas privadas. Na Idade Média, a constituição política é a constituição da propriedade privada, mas somente porque a constituição da propriedade privada é a constituição política. Na Idade Média, a vida do povo e a vida política são idênticas. O homem é o princípio real do Estado, mas o homem não livre. É, portanto, a democracia da não-liberdade, da alienação realizada. A oposição abstrata e refletida pertence somente ao mundo moderno. A Idade Média é o dualismo real, a modernidade é o dualismo abstrato. (MARX, 2010, p. 83)
\end{abstract}

Disponível em http://www.histedbr.fe.unicamp.br/acer_fontes/acer_marx/tme_13.pdf. Data de acesso: 03.09.2017. 
Desse modo, a exploração econômica no seio das atividades sociais, constitui a manipulação do poder econômico como forma de exercício da dominação, a criação de instrumentos de servilização do homem pelo homem, a formação de uma economia burguesa extraída da propriedade e da mercadoria a sua forma de instauração da diferença social, a coisificação humana nas relações sociais, a redução das capacidades humanas ao potencial mensurável de trabalho do homem, a alienação gerada pelo trabalho, a manutenção da hegemonia burguesa mantida com bases nas ideias de lei e ordem, seriam temas que alcançam grande significado na teoria marxista, inclusive, com alcance repercussão jurídico-política (BITTAR, ALMEIDA, 2015, p. 411).

Baseado na questão produtiva, intrínseca a vida material pelos homens que Marx desenvolverá, de forma especifica, um dos temas que eram ligados à tradição hegeliana, mas que, na sua visão, encontra-se inovado. As relações de produção, em seu quadro geral, apresentam uma serie de contradições contradição entre senhores e escravos ou entre senhores e servos, e, no presente, a contradição entre o burguês e o proletário revelam o fato de que massas de indivíduos não se assentam na produção de suas atividades e de sua vida em benefício próprio. O homem, afastado de suas possibilidades plenas, está alienado de si. Assim sendo, a alienação constitui uma das formas das mais nítidas condições do homem no sistema capitalista de produção. (MASCARO, 2016, p.249).

Segundo Mascaro (2016, p. 239), “tal contato com o pensamento de Hegel é decisivo para os passos iniciais do pensamento do próprio Marx. Seu doutorado em filosofia, uma comparação entre o atomismo em Demócrito e Epicuro, tem clara inspiração hegeliana". Por outro lado, a obra marxista vem marcada pela dualidade, pois de um lado tem uma influencia notadamente de Hegel e, também, do pensamento de Feuerbach. A perspectiva marxista não seria uma corrente a qual busca a conciliação entre ambos os pensamentos, mas sim uma proposta que abarca ambas as tendências. Marx não pode aceitar a especulação pura e racional idealista hegeliana, apesar de sua base na literatura de Hegel.

A lógica de exploração do capitalismo é distinta daquela do feudalismo ou do escravagismo. Não é pela força que o trabalhador se submete ao capital. É pela impossibilidade do domínio direto dos meios de produção que os trabalhadores são impulsionados a venderem o seu trabalho, seus corpos, sua inteligência e suas energias, como mercadoria, aos capitalistas, que entesouram a mais-valia desse esforço de multidões de 
pessoas $^{5}$. O trabalho não se constitui em razão de uma necessidade social, mas de um fim, o processo de valorização, de produção de riqueza. A lógica do capital contém, assim, a lógica de exploração do trabalho assalariado e a lógica da circulação universal de todas as pessoas e coisas como mercadorias. ${ }^{6}$

A "verdade" é centrada na forma do discurso científico e nas instituições que o produzem; está submetida a uma constante incitação econômica e política (necessidade de verdade tanto para a produção econômica, quanto para o poder político); é objeto, de várias formas, de uma imensa difusão e de um imenso consumo (nos aparelhos de educação ou de informação, cuja extensão no corpo social é relativamente grande); é produzida e transmitida sob o controle, não exclusivo, mas dominante, de alguns grandes aparelhos políticos ou econômicos (universidade, exército, escritura, meios de comunicação); enfim, é objeto de debate político e de confronto social, ou seja, as lutas ideológicas (FOUCAULT, 1979, p. 11).

[...] O intelectual tem especificidade em sua posição de classe, a qual Foucault faz referencia as seguintes: (pequeno burguês a serviço do capitalismo, intelectual "orgânico" do proletariado); a especificidade de suas condições de vida e de trabalho, ligadas à sua condição de intelectual (seu domínio de pesquisa, as exigências políticas a que se submete, na universidade, no hospital, etc.); ao fim, a especificidade da política de verdade nas sociedades contemporâneas. Ele funciona ou luta ao nível geral deste regime de verdade, que é tão essencial para as estruturas e para o funcionamento de nossa sociedade, exercendo papel importante para enfrentar a ideologia dominante (FOUCAULT, 1979, p. 12)

A perversidade sistêmica que está na raiz dessa evolução negativa da humanidade tem relação com a adesão desenfreada aos comportamentos competitivos que atualmente caracterizam as ações hegemônicas. Todas essas mazelas são direta ou indiretamente

\footnotetext{
${ }^{5} \mathrm{O}$ surgimento da lei fabril adicional de 7 de junho de 1844 , que entrou em vigor em 10 de setembro desse mesmo ano. Ela acolhia uma nova categoria de trabalhadores entre os protegidos: as mulheres maiores de 18 anos. Estas foram equiparadas aos adolescentes em todos os aspectos, seu tempo de trabalho foi limitado a 12 horas, o trabalho noturno lhes foi vetado etc. Pela primeira vez, a legislação se viu compelida a controlar direta e oficialmente também o trabalho dos adultos. No relatório de fábrica de 1844-1845, diz-se ironicamente: Não nos foi apresentado nem um único caso em que mulheres adultas tivessem se queixado de uma interferência em seus direitos. O trabalho de crianças menores de 13 anos foi reduzido para 6 horas e meia e, sob determinadas condições, para 7 horas diárias (MARX, 1996, p. 292).

${ }^{6}$ Produção capitalista, sendo produção de valor, tem necessariamente de ser produção de mais-valor. Mais-valor, por sua vez, subentende um processo por meio do qual um dos envolvidos no processo de produção - no caso, o trabalhador - produz mais valor do que recebe sob a forma de salário. Por conseguinte, a determinação da produção capitalista como produção de valor pressupõe a exploração do trabalhador, descoberta por Marx, e uma série de outras categorias fundamentais da economia capitalista: duplo caráter do trabalho, processo de trabalho e processo de valorização etc. O mais-valor, contudo, além de desvendar o mecanismo de acumulação de capital, isto é, a expropriação do trabalhador, expressa um processo ainda mais fundamental: mais do que significar a exploração do trabalho, como de fato o faz, o mais-valor representa a objetivação, estranhada dos sujeitos, do potencial que possui o trabalho (social) de reproduzir de forma ampliada as suas condições antecedentes. (MARX, Karl. Grundrisse, 1785, p. 25).
} 
imputáveis ao presente processo de globalização ${ }^{7}$. Por outro lado, a lógica da reprodução das condições de produção é uma imposição capitalista de controle social, que mantém a submissão de trabalhadores a reprodução dos meios de produção mediante a utilização dos meios e a repetição das condições de produção, o que gera a reprodução das condições materiais de produção para a satisfação do modelo capitalista. A reprodução da força do trabalho ocorre pela necessidade, no atual modelo, de que o indivíduo obtenha recursos mínimos para a subsistência da família ${ }^{8}$.

Desse modo, na visão marxista há uma relação bilateral entre o possuidor de dinheiro se encontram no mercado e estabelecem uma relação mútua como se "naturalmente" iguais possuidores de mercadorias, com a única diferença de que um é comprador e o outro, vendedor, sendo ambos, portanto, pessoas juridicamente iguais para fazerem um contrato mercantil. A continuidade dessa relação requer que o proprietário da força de trabalho a venda apenas por um determinado período, pois, se ele a vende integralmente, vende a si mesmo, transformando-se de um homem livre num escravo, de um possuidor de mercadoria numa mercadoria; assim, o oferecimento ao consumo deverá ser estabelecido por um período determinado, de tal modo que, o proprietário não renuncie na venda da força de trabalho seu direito absoluto de propriedade sobre ela.

O modelo de reprodução da força do trabalho é defendido desde a escola, quando o aluno, a contar da formação básica, aprende a ser submisso à estrutura do capital. Durante a educação fundamental e média, ao estudante é imposto o modelo dominante, da lógica capitalista da submissão, que prevê que o indivíduo deverá estudar para, após, trabalhar e ser disciplinado, possibilitando a sua sobrevivência e o sustento de sua família (ALTHUSSER, 1985, p.21). Com sapiência, ensina o autor:

\footnotetext{
${ }^{7}$ A globalização como fábula, se constrói a partir de fantasias. O mito ideológico está presente em situações corriqueiras (o encurtamento de distâncias, noções de tempo e espaço); a mensagem transmitida é como se essas coisas fossem possíveis de estar ao alcance da mão, quando, na realidade, ocorrem em sentido contrário. Estas ideais fabricadas como algo inerente a cidadania universal, seriam fábulas que alimentam o sistema mercantilista global, como capaz de homogeneizar o planeta numa "linguagem única", acessível a todos, quando, na verdade, as diferenças locais são extremamente aprofundadas. (SANTOS, 2001, p. 18).

${ }^{8}$ Por força de trabalho ou capacidade de trabalho entendemos o complexo [Inbegriff] das capacidades físicas e mentais que existem na corporeidade [Leiblichkeit], na personalidade viva de um homem e que ele põe em movimento sempre que produz valores de uso de qualquer tipo. No entanto, para que o possuidor de dinheiro encontre a força de trabalho como mercadoria no mercado, é preciso que diversas condições estejam dadas. A troca de mercadorias por si só não implica quaisquer outras relações de dependência além daquelas que resultam de sua própria natureza. Sob esse pressuposto, a força de trabalho só pode aparecer como mercadoria no mercado na medida em que é colocada à venda ou é vendida pelo seu próprio possuidor, pela pessoa da qual ela é à força de trabalho. Para vendê-la como mercadoria, seu possuidor tem de poder dispor dela, portanto, ser o livre proprietário de sua capacidade de trabalho, de sua pessoa. (MARX, 2011, p. 206)
} 
Neste sentido, é feita a seguinte pergunta: Como é assegurada a reprodução da força de trabalho no regime capitalista? Segundo Althusser, é assegurada dando à força de trabalho o meio material de se reproduzir: o salário. $O$ salário figura na contabilidade de cada empresa, como capital mão de obra e de modo algum como condição da reprodução material da força de trabalho? Diferentemente do que se perpassava nas formações sociais escravagistas e feudais, esta reprodução da qualificação da força de trabalho tende (trata- se de uma lei tendencial) a ser assegurada não em cima das coisas (aprendizagem na própria produção), mas, e cada vez mais, fora da produção: através do sistema escolar. A reprodução da força de trabalho tem, pois como condição sine qua non não só a reprodução da qualificação desta força de trabalho, mas também a reprodução da sua sujeição à ideologia dominante ou da prática desta ideologia, com tal precisão que não basta dizer: não só, mas também, pois se conclui que é nas formas e sob as formas da sujeição ideológica que é assegurada a reprodução da qualificação da força de trabalho (Althusser, 1985 p. 22).

O autor retomando as proposições, célebres do materialismo histórico de Marx (baseado, fundamentalmente, nas relações sociais, históricas, produtivas, etc), que concebe a estrutura de qualquer sociedade como constituída pelos níveis ou instâncias, articulados por uma determinação específica. Essa determinação terá como ponto de partida a infraestrutura ou base econômica, que o autor denomina de unidade das forças produtivas e das relações de produção e a superestrutura que comporta em si mesmas duas instâncias: a jurídico-política (o Direito e o Estado), e as diferentes ideologias (religiosas, moral, jurídica, politica, etc.)

Sendo assim, tomando por base as lições do materialismo histórico marxista, parte do pressuposto que a história tem seu perfazimento não nos indivíduos, mas sim na raiz econômica produtiva da sociedade, ou seja, nas condições materiais de vida. No capitalismo, para que haja exploração, os trabalhadores e os burgueses devem ser tornados "iguais" por uma instância política terceira, que seja distinta de ambos. O Estado moderno cumpre esse papel. Mas não o cumpre porque seja, de fato, a unificação geral dos interesses, o bem comum. O Estado surge como condição estruturante da exploração jurídica do trabalho.

O contrato de trabalho, portanto, será celebrado entre dois sujeitos em condição de estrita reciprocidade, por um ato livre da vontade do trabalhador, sem qualquer forma de coerção estatal obrigando-o a realizar essa operação jurídica. O poder do Estado pode então aparecer como estando acima das partes contratantes, como uma autoridade pública que apenas vela pela observância da ordem pública, isto é, das condições de funcionamento normal do mercado e da livre iniciativa entre as partes contratantes.

Desse modo, segundo o marxismo, o Estado seria uma forma de opressão especificamente capitalista; o aparato político estatal moderno põe em funcionamento a possibilidade da reprodução contínua da exploração do trabalho por meio dos vínculos 
mercantis, fazendo do trabalhador uma mercadoria a ser vendida, cuja mais-valia é apropriada como riqueza pelo burguês. No próximo ponto será abordada, a relação entre o direito e o marxismo, buscando elencar a forma como o direito reproduz a lógica predominante do capital, das relações produtivas do sistema.

\section{MARX E A CRÍTICA DOS DIREITOS HUMANOS}

O primeiro fundamento decisivo para a elaboração de uma teoria marxista do direito é estudar as relações jurídicas a partir do seu caráter radicalmente histórico e social. A historicidade do direito nos leva à compreensão do fenômeno jurídico como realidade objetiva, como um complexo de relações sociais, a partir das suas contradições.

Desse modo, o sentido das categorias jurídicas, tais como sujeito de direito, norma jurídica, relação jurídica, liberdade, igualdade, autonomia da vontade, entre outras, como expressão de formas de ser, de determinações realmente existentes, ou seja, no plano real. Por isso, cabe a uma teoria crítica do direito analisar quais as condições materiais, reais, sociais, que criaram a forma jurídica, como se deu o desenvolvimento do direito ao longo da história das sociedades de classes e quais os limites históricos de aplicação dos conceitos jurídicos (PEREIRA, 2015, p. 33).

Marx irá proceder, em toda a sua obra, a uma compreensão mais bem aclarada dos mecanismos dessa práxis, da relação do homem com a natureza, percebendo, daí, a instância fundamental, para a própria constituição da humanidade como tal e de sua sociabilidade, da produção. Nas relações produtivas, assenta-se, pois, a forma determinante da própria historicidade humana, posto que certas instâncias que tradicionalmente eram consideradas fundantes do próprio homem e suas constituintes maiores estão, na verdade, na dependência direta dessas relações produtivas. Dirá Marx,

A minha investigação desembocava no resultado de que tanto as relações jurídicas como as formas de Estado não podem ser compreendidas por si mesmas nem pela chamada evolução geral do espírito humano, mas se baseiam, pelo contrário, nas condições materiais de vida cujo conjunto Hegel resume, seguindo o precedente dos ingleses o franceses do século XVIII, sob o nome de "sociedade civil", e que a anatomia da sociedade civil precisa ser procurada na economia política. Em Bruxelas, para onde me transferi, em virtude de uma ordem de expulsão imposta pelo Sr. Guizot, tive ocasião de prosseguir nos meus estudos de economia política, Iniciados em Paris. O resultado geral a que cheguei e que, uma vez obtido, serviu de fio condutor aos meus estudos, pode resumir-se assim: na produção social da sua vida, os homens contraem determinadas relações necessárias e independentes da sua vontade, relações de produção que correspondem a uma determinada fase de 
desenvolvimento das suas forças produtivas materiais. O conjunto dessas relações de produção forma a estrutura econômica da sociedade, a base real sobre a qual se levanta a superestrutura jurídica e política e à qual correspondem determinadas formas de consciência social. (Contribuição à crítica da economia política)

Nesse sentido, essa fase será denominada de "primeiro marxismo", à medida que Marx irá proceder a descoberta filosófica de que o sujeito seria o agente da transformação social, não será a consciência do homem que determinará a o seu ser enquanto sujeito, mas, de outro modo, o seu ser social é que determina a sua consciência. Ao chegar a uma determinada fase de desenvolvimento, as forças produtivas materiais da sociedade se chocam com as relações de produção existentes, ou, o que não é senão a sua expressão jurídica, com as relações de propriedade que irão se desenvolver. O modo de produção da vida material é o elemento condicionante da totalidade das relações (vida social, política, religião) ${ }^{9}$.

A crítica da economia política consiste, justamente, em mostrar que, apesar das afirmações greco-romanas e liberais de separação entre a esfera privada da propriedade e a esfera pública do poder, a política jamais conseguiu realizar essa diferença. O poder político sempre foi à maneira jurídica pela qual a classe dominante de uma determinada sociedade manteve seu domínio. O aparato legal e jurídico apenas dissimula o essencial: que o poder político serve aos interesses e privilégios, do poder economicamente dominante, para garantirlhes a dominação social. Divididas entre proprietários e não proprietários (trabalhadores livres, escravos, servos), as sociedades jamais foram comunidades fruto da igualdade real ${ }^{10}$.

Ao analisar o direito moderno e a função que exerce este direito em nossa sociedade burguesa, Marx encara como uma criação do indivíduo, mas como um instrumento a serviço de uma classe, denominada de classe burguesa/capitalista, uma das entidades coletivas que compõem a sociedade; tal classe se caracteriza por seu papel de detentora dos meios de produção, denominada de classe dominante. Assim, o direito terá uma finalidade necessária e,

\footnotetext{
9 Marx além da questão religiosa (alienação) investigou, sobretudo, a alienação social. Interessou-se na compreensão de causas pelas quais os homens ignoram que são os criadores da sociedade, da política, da cultura e agentes da História, o porquê os humanos acreditam que a sociedade não foi instituída por eles, mas por vontade e obra dos deuses, da Natureza, da Razão, em vez de perceberem que são eles próprios que, em condições históricas determinadas, criam as instituições sociais família, relações de produção, de trabalho, relações de troca, linguagem oral, linguagem escrita, escola, religião, artes, ciências, filosofia e as instituições políticas, leis, direitos, deveres, tribunais, Estado, exército, impostos, prisões. A ação sociopolítica e histórica chama-se práxis e o desconhecimento de suas origens e de suas causas, alienação. (CHAUÍ, 2002, p. 216).

${ }^{10}$ Nas sociedades pré-capitalistas, as relações de produção não se fundam em categorias jurídicas. O escravismo e o feudalismo são modos de produção de exploração direta. Neles, até as normatividades existentes - e que muitas vezes podem ser chamadas, de modo inespecífico, por "direito" não funcionam segundo a forma que vai se estabelecendo na modernidade. O mando é direto, como se vê nas figuras típicas do senhor de escravo e do senhor feudal. As normas, nessas sociedades, são um modo de arranjo dos que detêm o poder bruto e direto. Não se separam a instância política e os dominantes da sociedade. (MASCARO, 2017)
} 
também, de certo ideológica, a burguesia realizará sua forma de dominação e, assim, terá o controle e funcionamento da economia de acordo com seus interesses classistas.

Nesse sentido, Marx se satisfaz com esta visão da finalidade do direito. Segundo a Crítica ao Programa de Gotha (1875), na qual Marx desenvolve especialmente seus pontos de vista sobre o direito, na sociedade comunista, que será de abundância, o direito futuro distribuirá "a cada um conforme sua necessidade". No entanto, tendo então sobrestado de ser um instrumento de dominação de uma classe sobre outra, talvez não seja mais conveniente designá-lo pelo termo direito pelo seu perecimento. (VILLEY, 2008, pp. 170 - 171). Em a questão judaica, Marx elenca que toda emancipação é redução do mundo humano e suas relações ao próprio homem. A emancipação política é a redução do homem, por um lado, a membro da sociedade burguesa, a indivíduo egoísta independente, e, por outro, a cidadão, a pessoa moral.

A constituição do Estado político e a dissolução da sociedade burguesa nos indivíduos independentes cuja relação é baseada no direito, assim como a relação do homem que vivia no estamento e na guilda tinha como base o privilégio. O homem, na qualidade de membro da sociedade burguesa, o homem apolítico, necessariamente se apresenta então como o homem natural. O Estado será a forma através da qual os indivíduos de uma classe dominante farão valer os seus interesses comuns e na qual se resume toda a sociedade civil, valendo prevalecer a idéia as instituições públicas têm o Estado como intermediário; a lei repousará sobre uma "vontade livre", desligada da sua base concreta e o direito, por sua vez, reduzido à lei.

$\mathrm{O}$ direito privado exprime as relações de propriedade existentes como o resultado de uma vontade geral, que para Marx não passa de mera ilusão jurídica. O próprio jus utendi et abutendi exprime, por um lado, o fato de a propriedade privada se tornar completamente independente da comunidade e, por outro, a ilusão de que essa propriedade privada repousa sobre a simples vontade privada e livre disposição das coisas. (MARX, 2010, p. 65). Assim,

De acordo com Bauer, o homem deve renunciar ao "privilégio da fé" para poder acolher os direitos humanos universais. Observemos por um momento os assim chamados direitos humanos, mais precisamente os direitos humanos sob sua forma autêntica, ou seja, sob a forma que eles assumem entre seus descobridores, entre os norte-americanos e franceses! Esses direitos humanos são em parte direitos políticos, direitos que são exercidos somente em comunhão com outros. O seu conteúdo é constituído pela participação na comunidade, mais precisamente na comunidade política, no sistema estatal. Eles são classificados sob a categoria da liberdade política, sob a categoria dos direitos do cidadão, os quais, como vimos, de modo algum pressupõem a superação positiva e irrefutável da religião, e, portanto, inclusive por exemplo do judaísmo. Resta, então, analisar a outra parte dos direitos 
humanos, os droits de l'homme (direitos do homem), na medida em que são distintos dos droits du citoy en (direitos do cidadão). (MARX, 2010, p. 57)

Para Marx existe a incompatibilidade entre religião e direitos humanos e, por consequência o distanciamento do horizonte dos direitos humanos ligada ao aspecto da liberdade de religião, em sua particularidade e exercício de culto, o qual enquanto privilégio da fé constituiria um direito humano universal. A questão central na visão marxista em que discorrerá sua análise está na diferenciação entre direitos do homem (droits de 1'homme) e direitos do cidadão (droits du citoy) em que Marx questiona, quem é esse homem diferenciado do cidadão? Como resposta seria o homem enquanto membro da sociedade burguesa ${ }^{11}$.

Marx exemplifica que a renda de um terreno seja suprimida pela concorrência; o proprietário desse terreno conserva seu título jurídico sobre esse terreno bem como seu jus utendi et abutendi. Ele não será considerado "proprietário fundiário", se não possuir, além disso, capitais suficientes para cultivar o seu terreno. A perspectiva marxista irá denomina de ilusão jurídica, para os juristas e os códigos existentes, por se tratar de algo casual, uma vez, os indivíduos estabeleceram relações entre si, por contrato subscrito conforme um acordo de vontades, que será realizado de acordo vontade arbitrária e individual dos contratantes, com a chancela obrigatória do direito, quanto à integração das partes nos moldes de aquisição da propriedade (indivíduos livres -liberdade, igualdade - iguais, propriedade -proprietários).

Na Sagrada família, continua Marx ao tratar dos direitos humanos de forma crítica, elencando que o reconhecimento dos direitos humanos pelo Estado moderno tem o mesmo sentido que o reconhecimento da escravidão pelo Estado antigo. Com efeito, assim como o Estado antigo tinha por fundamento natural a escravidão, o Estado moderno tem como base natural a sociedade burguesa e o homem da sociedade burguesa, isto é, o homem independente, ligado ao homem somente pelo vínculo do interesse particular e da necessidade natural inconsciente, tanto a própria como a alheia. O Estado moderno reconhece esta sua base natural, enquanto tal, nos direitos gerais do homem.

11 O direito privado exprime-se as relações de propriedade existentes como sendo o resultado de uma vontade geral. O próprio jus utendi et abutendi (direito de usar e abusar) exprime, por um lado, o ato de que a propriedade privada se tornou completamente independente da comunidade e, por outro lado, a ilusão de que essa propriedade privada repousa sobre a simples vontade privada, sobre a livre disposição das coisas. Na prática, o abuti (direito de abusar) tem limites econômicos bem determinados para o proprietário privado, se este não quiser ver sua propriedade, e com ela seu jus abutendi, passar para outras mãos; pois, afinal de contas, a coisa, considerada unicamente em suas relações com sua vontade, não é absolutamente nada, mas somente no comércio, e independentemente do direito, torna-se uma coisa, uma propriedade real (uma relação, aquilo que os filósofos chamam uma ideia). Essa ilusão jurídica, que reduz o direito à simples vontade leva fatalmente, com o ulterior desenvolvimento das relações de propriedade, a que alguém possa ter um título jurídico de uma coisa sem possuir realmente esta coisa. (MARX, 2010,pp. 75-77). 
Para Mascaro (2016, p. 260), “essa perspectiva de Marx liberta a compreensão dos direitos humanos da tradição moderna, que entendia serem tais direitos expressão de um justo natural, ou então direitos da natureza intrínseca do homem”. Marx salienta que embora o estado reconheça os direitos humanos e do homem, ele não seria seu criador. Nesse sentido, a problemática enfrentada pelo marxismo em relação aos direitos humanos, está relacionada ao problema da liberdade real, concreta, e não apenas a liberdade e a isonomia formal forma perante a lei e as declarações de direitos do homem. Sendo assim, o exercício pleno dos direitos humanos, só tem resolução, na vertente marxista, pela práxis revolucionária e não pela mera declaração e proclamação de direitos.

Cabe salientar, que logo em suas primeiras obras, Marx já expõe a associação indissolúvel entre o direito e a estrutura material do capitalismo. Da mesma forma que o Estado, o direito não nascerá da vontade geral, portanto não é fundado no contrato social, nem numa pretensa paz social ou congêneres, nem de um direito natural, eterno e de caráter racional como preceituava a fórmula contratualista de Jean Jaques Rousseau ${ }^{12}$. Toda a lógica do direito não está ligada às necessidades de bem comum, nem a verdades jurídicas transcendentes. Está ligada, sim, à própria práxis, à história social e produtiva do homem.

Sendo assim, a propriedade não é vista como um direito natural de todo indivíduo, nem como uma conquista da humanidade em favor do equilíbrio social. A propriedade privada não é um mal em si, mas o uso que dela se faz é suficiente para a desigualdade das classes e a exploração. A propriedade é vista como o ingrediente que diferencia os homens entre si, que causa distorções entre as classes sociais, que assegura a manutenção dos interesses do poder e de alienação do proletariado pela servilização do trabalho; em suma, trata-se de uma forma de exploração. É ela que instaura a diferença entre o possuidor e o despossuído, em face dos instrumentos de produção. Segundo Engels,

As relações econômicas e sociais, anteriormente representadas como criações do dogma e da Igreja, porque esta as sancionava, agora se representam fundadas no direito e criadas pelo Estado. Visto que o desenvolvimento pleno do intercâmbio de

\footnotetext{
${ }^{12}$ Seja qual for o caminho que nos faça regressar ao princípio, sempre chegaremos à mesma conclusão: que o pacto social estabelece entre os cidadãos uma tal igualdade que todos ficam obrigados às mesmas condições e todos devem gozar dos mesmos direitos. E assim, pela natureza do pacto, todo o ato de soberania, isto é, todo o autêntico ato de uma vontade geral, obriga ou favorece igualmente todos os cidadãos; de tal modo que o soberano apenas conhece a nação e não distingue ninguém entre aqueles que a compõem. O que é isto, senão um ato de soberania? Não é um acordo, entre o superior e o inferior, mas um pacto entre o todo e cada um dos seus membros: pacto legítimo, pois tem por base o contrato social; equitativo, por ser comum a todos; útil, porque só pode ter como finalidade o bem geral; e sólido, uma vez que tem por garantia a força pública e o poder supremo (ROSSEAU, 2010, p. 46).
} 
mercadorias em escala social - isto é, por meio da concessão de incentivos e créditos, engendra complicadas relações contratuais recíprocas e exige regras universalmente válidas, que só poderiam ser estabelecidas pela comunidade normas jurídicas estabelecidas pelo Estado, imaginou-se que tais normas não proviessem dos fatos econômicos, mas dos decretos formais do Estado. Além disso, uma vez que a concorrência, forma fundamental das relações entre livres produtores de mercadorias, é a grande niveladora, a igualdade jurídica tornou-se o principal brado de guerra da burguesia. Contribuiu para consolidar a concepção jurídica de mundo o fato de que a luta da nova classe em ascensão contra os senhores feudais e a monarquia absoluta, aliada destes, era uma luta política, a exemplo de toda luta de classes, luta pela posse do Estado, que deveria ser conduzida por meio de reivindicações jurídicas (ENGELS, 2012, p. 19).

Engels desenvolverá em parceria com Karl Kautsky, sua reflexão sobre o direito, Ambos sustentam que, a percepção de que relegar o fato apenas ao jurídico não possibilitava eliminar as adversidades criadas pelo modo de produção burguês-capitalista, ou seja, a grande indústria moderna do século XVIII. As primeiras formações partidárias proletárias, assim como seus teóricos, mantiveram de forma estrita no "terreno do direito", embora edificasse para si horizonte do direito contrário à burguesia.

De um lado, a reivindicação de igualdade foi estendida, buscando completar a igualdade jurídica com a igualdade social. De outro, citando Adam Smith, o trabalho é a fonte de toda a riqueza, mas o produto do trabalho dos trabalhadores deve ser dividido com os proprietários de terra e os capitalistas, pois essa divisão não seria justa e deveria ser abolida/modificada em favor dos obreiros. O capitalismo não vincula o trabalhador ao burguês por conta da violência bruta deste contra aquele, mas sim a partir do vínculo entre ambos por intermédio de um contrato de trabalho (ENGELS, 2010, p. 20). Ensina Marx:

Na esfera da circulação ou do intercâmbio de mercadorias, dentro de cujos limites se movimentam compra e venda de força de trabalho, era de fato um verdadeiro éden dos direitos naturais do homem. Marx irá dizer que os ideários da Revolução Francesa (Liberdade, Igualdade, Propriedade) estão ligados ao livre comércio; isto porque, o comprador e vendedor de uma mercadoria, por exemplo, da força de trabalho, são determinados apenas por sua livre-vontade. Contratam como pessoas livres, juridicamente iguais. O contrato é o resultado final, no qual suas vontades se dão uma expressão jurídica em comum, ou seja, a partir da igualdade das partes, tendo em vista que ambos relacionam um com o outro apenas como possuidores de mercadorias e trocam equivalente por equivalente, ou seja, a propriedade. O único poder que os junta e leva a um relacionamento é o proveito próprio, a vantagem particular, os seus interesses privados. E justamente porque cada um só cuida de si e nenhum do outro, realizam todos, em decorrência de uma harmonia preestabelecida das coisas ou sob os auspícios de uma previdência toda esperta, tão-somente a obra de sua vantagem mútua, do bem comum, do interesse geral (MARX, 1996, p. 280). 
Como qualquer burguês e qualquer trabalhador podem contratar a compra-e-venda do trabalho, o direito é o instrumento fundamental dessa circulação contínua da mercadoria trabalho e, indissolúvel. A relação entre circulação e direito não é apenas fundamental para a circulação dos bens no comércio. A própria lógica da produção é juridicamente mercantilizada, estruturada a partir do trabalho como uma mercadoria qualquer vendida no mercado. O salário não se explica em razão do seu valor intrínseco ou da mera deliberação do capitalista. A lógica do trabalho está atrelada a uma dinâmica da sua circulação como valor de troca. As fórmulas que regem o direito das obrigações, dar e fazer, são para Marx as mesmas para o comércio e para a exploração do trabalho (MASCARO, 2016, pp. 261 - 262).

Vale fazer menção aos direitos constitucionais de primeira geração (liberdade de pensamento e expressão, igualdade, voto). Na obra 18 Brumário, Marx irá destacar que a classe dominante se mobiliza para liquidação não apenas do movimento socialista, mas também das instituições, em razão do paradoxo estabelecido entre o interesse da propriedade privada e do negócio; desse modo, direitos civis, a liberdade de imprensa, a liberdade de reunião, o direito ao sufrágio universal foram sacrificados a esse interesse para que a burguesia pudesse, sob a proteção de um governo forte e irrestrito, dedicar-se aos seus negócios privados. Ela declarou inequivocamente que estava ansiosa por desobrigar-se do seu próprio domínio político para livrar-se, desse modo, das dificuldades e dos perigos nele implicados. O Poder Executivo se converte em poder autônomo.

O direito, em Marx, não assume como era própria da filosofia do direito na modernidade, ou seja, característica de idéia ou de conceito que melhor faça justiça à realidade. Não evolui pelo melhor aclaramento da consciência do jurista, nem tampouco pela melhor elaboração dos conceitos. Na verdade, evolui pela necessidade das relações produtivas de estabelecerem determinadas instâncias que possibilitem o próprio funcionamento do sistema. Na circulação da produção, na exploração da mais-valia, no lucro, no contrato, enfim, o direito desempenha papel fundamental de estruturação das próprias relações materiais e econômicas do sistema de produção capitalista.

O Direito não é nem instrumento para a realização da justiça, nem a emanação da vontade do povo (volkgeist), ou vontade do legislador, mas uma superestrutura ideológica a serviço das classes dominantes. A ordem instaurada pela regra jurídica é causa de manutenção das distorções político-econômicas, onde a base das desigualdades sociais e da exploração do proletariado, em que Estado e Direito estarão conexos para atenderem aos interesses de classe. Durante a instalação da ditadura proletária, ainda que transitória, há Direito. Após a ditadura 
do proletariado, e o gradativo desmantelamento das estruturas jurídicas e burocráticas, passará a vigorar uma situação comunista, em que o Direito é algo dispensável, em face da própria igualdade de todos. Abolida a divisão de classes sociais, o Estado desaparece, porque é mera expressão da dominação de uma classe sobre outra (BITTAR, ALMEIDA, 2015, p. 419)

Marx, na dialética materialista e histórica, rompe definitivamente com esse passado filosófico moderno. Com seu pensamento, necessariamente, toda a filosofia contemporânea deverá dialogar. A filosofia para a transformação se inscreve como máxima imperiosa de nossos tempos. Por isso, numa filosofia do direito que, quando assume ares de crítica, pensa botar em criar algo novo, quando em verdade coloca em contradição toda a edificação do passado, tais momentos superlativos da história da filosofia do direito é entender parte de nosso tempo e é entender melhor os problemas e as transformações necessárias da atualidade.

$\mathrm{Na}$ idéia de cada qual, segundo sua capacidade; a cada qual, segundo suas necessidades, a perspectiva marxista parece ter inscrito um ideal de justiça que se insere na relação laboral e nas necessidades humanas, as quais não são eminentemente formais ou individualizadas, mas como resultado da lógica mercantil, de acordo com as condições do homem e tendo em vista suas necessidades. Esta ilusão jurídica, que reduz o direito à simples vontade, que explica o fato de, para os juristas e para os códigos jurídicos, as relações entre os indivíduos celebrados por contratos, na medida em que o seu conteúdo repousa inteiramente sobre a vontade arbitrária e individual de uma das partes contratantes: a classe burguesa.

\section{CONCLUSÃO}

Mister a luz de tais constatações, sem exaurir a temática abordada, para o marxismo, as forças econômicas em interação na história, a luta de classes é o vetor móvel da sociedade, a servilização do homem pelo trabalho, acerca do papel existencial do homem, sendo fatores que destacam o marxismo para uma forte crítica social. E isso é analisado na teoria marxista não somente como um fato contemporâneo e passageiro, mas também como uma constante histórica, que, por forçosamente presente, haveria de gerar a opressão burguesa em face da fraqueza proletária.

Os proprietários dos meios de produção podem ter interesses comuns, pois necessitam do intercâmbio e da cooperação para manter e fazer crescer a propriedade de cada um. Assim, embora estejam em concorrência, precisam estabelecer certas regras pelas quais não se destruam reciprocamente nem às suas propriedades. É preciso, portanto, que os interesses 
comuns entre os proprietários dos meios de produção e a força para dominar os nãoproprietários, sejam estabelecidos de maneira tal que pareçam corretos, legítimos e válidos para todos, tendo sido criado uma instancia acima da sociedade e das classes, o estado enquanto portador do direito e das leis, dotado de força para usar a violência legitima para reprimir qualquer ameaça à estrutura econômica existente.

O pensamento marxista encontra seus reflexos na área do Direito, notadamente, nos direitos humanos, apesar de não ver neste a saída para a história das iniquidades praticadas do homem sobre homem, de sociedade para sociedade. Sua crítica aos direitos humanos parte da sociedade feudal que havia sido dissolvida em seu fundamento, no homem, só que no tipo de homem que realmente constituía esse fundamento (no homem egoísta membro da sociedade burguesa), passa a ser a base, o pressuposto do Estado político, o qual assim o reconhece nos direitos humanos, de forma que reconhecimento dos direitos acabam sendo constituídos pelos elementos espirituais e materiais que constituem seu teor vital vinculado ao egoísmo da religião, da propriedade privada e do comércio, sob um ponto de vista meramente formal das declarações de direitos e, não uma realidade concreta no plano da igualdade material.

\section{REFERENCIAS}

ALTHUSSER, Louis. Aparelhos Ideológicos do Estado. Rio de Janeiro: Edições Graal, 1985, 2. ${ }^{a}$ Edição. Tradução: Walter José Evangelista e Maria Laura Viveiros de Castro.

BOBBIO, Norberto. Marx y el Estado. Ni con Marx ni contra Marx. Fondo de Cultura Económica, México, 1999. Cap. VII, pp. 132-147.

. O Conceito de sociedade civil; tradução de Carlos Nelson Coutinho. - Rio de Janeiro: Edições Graal, 1982.

. Dicionário de política. Brasília: Editora: Universidade de Brasília, 1998.

BITTAR, Eduardo, ALMEIDA, Guilherme de Assis. Curso de Filosofia do Direito. São Paulo, Atlas 2004.

BOGO, Ademar (Org.). Teoria da Organização Política: escritos de Engels, Marx, Lênin, Rosa, Mao - 1.ed. - São Paulo: Expressão Popular, 2005.

CHAUÍ, Marilena. Convite a Filosofia. Ed. Ática, São Paulo, 2000.

ENGELS, Friederich. O Socialismo Jurídico; tradução Lívia Cotrim e Márcio Bilharinho Naves. - São Paulo: Boitempo, 2012. 
FOUCAULT, Michel. Microfísica do Poder. Organização e tradução de Roberto Machado. Rio de Janeiro: Edições Graal, 1979.

LENIN, Vladimir. O Estado e a Revolução. Publicações da Liga Bolchevique

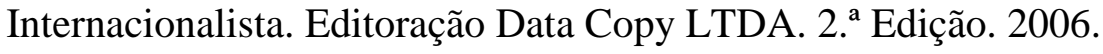

MARX, Karl e ENGELS, Friedrich. Sobre a Questão Judaica; apresentação e posfácio: Daniel Bensaïd; tradução Nélio Schneider, [tradução de Daniel Bensaïd, Wanda Caldeira Brant].São Paulo : Boitempo, 2010.

Manifesto do Partido Comunista. Editora Fonte Digital, 1999.

. Crítica da Filosofia do Direito de Hegel, 1843; tradução de Rubens Enderle e Leonardo de Deus - São Paulo: Boitempo, 2010.

O De 18 de Brumário de Luís Bonaparte / Karl Marx; tradução e notas Nélio Schneider; prólogo Herbert Marcuse. - São Paulo: Boitempo, 2011.

. Crítica da Economia Política. Volume I. O Processo de Produção do Capital: Prefácios e Capítulos I a XII - Editora Nova Cultural - São Paulo, 1996.

. Grundisse (1857 -1858). Tradutor: Nélio Schneider. Editora Boitempo, 2011.

MASCARO, Alysson Leandro. Direitos Humanos: Uma critica marxista. Lua Nova, São Paulo, 101: 109-137, 2017

. Filosofia do Direito. São Paulo: Atlas, 2016.

. Introdução ao Estudo do Direito. - 4.ed. - São Paulo: Atlas, 2013.

. Lições de Sociologia do Direito - São Paulo: Quartier Latin, 2007.

2002.

Introdução à filosofia do direito: dos modernos aos contemporâneos: São Paulo: Atlas,

MAGALHÃES, Fernando. 10 Lições de Marx. 3.ed.- Petrópolis, RJ: Vozes, 2013.

NADER, Paulo. Filosofia do Direito. Rio de Janeiro: Forense, 2012.

PEREIRA, Francisco. Karl Marx e o Direito: Elementos para uma crítica marxista do direito. Salvador/BA: LeMarx, 2015.

ROSSEAU, Jean Jacques. O Contrato Social: Editora Presença - Portugal, 2010.

SANTOS, Milton. Por uma outra globalização: do pensamento único 6' ed. à consciência universal. - 6* ed. - Rio de Janeiro: Record, 2001.

VILLEY, Michel. Filosofia do direito: definições e fins do direito: os meios do direito: 2. ed. São Paulo: Martins Fontes, 2008. - (Coleção justiça e direito). 